\title{
Quantification of macular ischaemia in sickle cell retinopathy
}

\author{
CAROL M LEE, HOWARD C CHARLES, R THEODORE SMITH, \\ NEAL S PEACHEY, JOSE G CUNHA-VAZ, AND MORTON F GOLDBERG
}

From the 'Department of Ophthalmology, University of Illinois College of Medicine at Chicago, USA

SUMmARY Macular ischaemia has a central role in the pathophysiology and prognosis of retinal macular disease. We attempted to quantitate two of its major components as follows: vascular nonperfusion, by measuring the foveal avascular zone (FAZ), using fluorescein angiography; and functional damage, using automated perimetry of the central $30^{\circ}$. Sickle cell disease was chosen for study because it was considered a prototype for a purely ischaemic retinopathy without an exudative component. We found that the FAZ measurement was reproducible and that the patients with maculopathy had statistically larger FAZs than the normal controls $(p=0 \cdot 016$, Wilcoxon rank sum test). In addition, scotomas measured by visual field perimetry were significantly larger in the sickle cell patients with maculopathy than in those without maculopathy. Our results showed that angiography and perimetry of the central $30^{\circ}$ were more sensitive tests for the detection of ischaemic macular disease than visual acuity and that macular ischaemia could be quantified by their use.

\begin{abstract}
Retinal vascular disease has two major pathophysiological processes: alteration of the blood-retinal barrier (BRB), as reflected by capillary leakage, and ischaemia, as manifested by vascular closure.' Leakage has been measured quantitatively with vitreous fluorophotometry by Cunha-Vaz et al..$^{23}$ and others. ${ }^{+}$Although vascular closure throughout the fundus has been demonstrated with widefield angiography in studies by Shimizu et al. ${ }^{5}$ and Niki and coworkers," the methodology is not yet available to quantify such closure accurately.

Visual field testing has been used to measure functional damage from retinal disease in diabetes and branch vein occlusions ${ }^{7 x}$ in an attempt to correlate dysfunction with the amount of damage from capillary non-perfusion.

We studied patients with sickle cell disease, which is considered a prototype for purely ischaemic retinopathy. A recent investigation" showed that the BRB was normal in sickle cell patients with background retinopathy as measured by fluorescein leakage on vitreous fluorophotometry; leakage was evident only when peripheral neovascularisation was also present.
\end{abstract}

Correspondence to Morton F Goldberg, MD, 1855 W Taylor Street, Chicago, IL 60612, USA.
We applied both fluorescein angiography and visual field perimetry to quantify vascular closure and retinal tissue function in sickle cell patients with and without observable maculopathy and in normal controls.

\section{Materials and methods}

\section{PATIENTS}

We reviewed the medical records of 186 consecutive patients being followed up in the Sickle Cell Eye Center and recruited those patients with ophthalmoscopic evidence of the macular depression sign " or angiographic evidence of arteriolar occlusion in the macular. Eyes that had undergone prior laser photocoagulation, cryotherapy, or intraocular surgery were excluded. All patients had electrophoretic confirmation of SS, SC, SA or S-thalassaemia haemoglobin. Patients with a visual acuity worse than $20 / 50$, cloudy media (that is, cataract, vitreous debris), glaucoma, unrelated retinal disease such as diabetes or sarcoidosis, or an unrelated cause for a visual field defect were excluded. Of 40 patients who had macular disease as defined above, 10 (group A) met our criteria for this study. The test eye had the more severe retinopathy of the two eyes. 


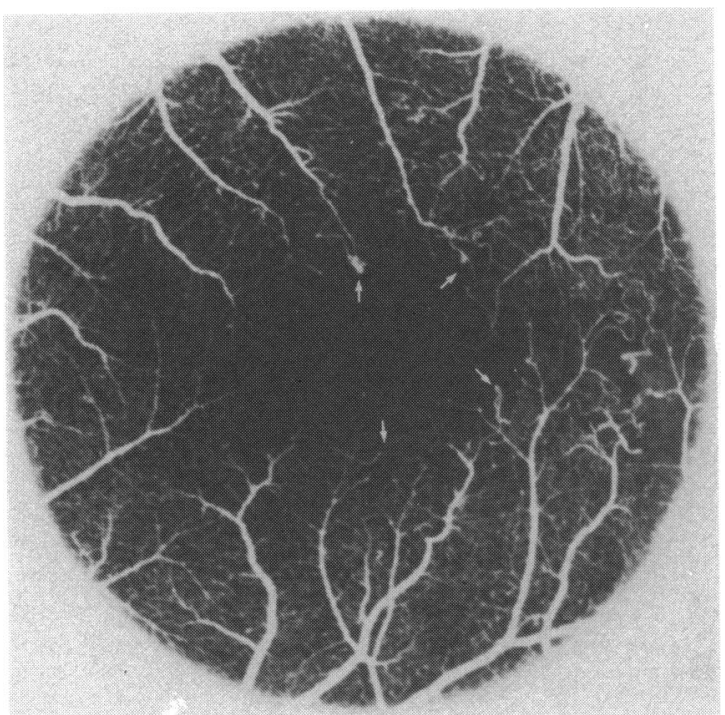

Fig. 1 Flrurescein angiogram of left eye of 46-year-old SC patient (group A, case 10). The longest diameter of the FAZ is $1.42 \mathrm{~mm}$. Note irregularity of outline and terminal occlusions (arrows). Visual acuity is 20/20.

We selected another 20 eyes of sickle cell patients with no evidence of macular disease either on ophthalmoscopic examination or by angiography. We divided the 20 eyes into one group of 10 (group B) which underwent angiography and a second group of 10 (group C) which underwent perimetry. One eye of

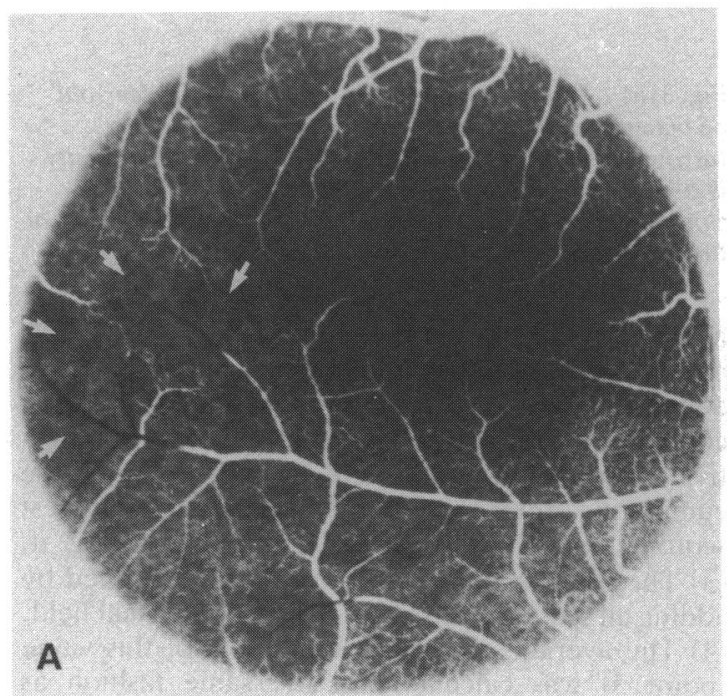

one patient whose other eye was included in group $\mathrm{A}$ (patient 4, Table 1) was included in group $B$ (patient 5 , Table 2). In all other cases only one eye was tested in any patient. The eye with the most severe retinopathy was chosen. Groups B and C were matched with group $\mathrm{A}$ for age (see Tables 1,2,3). Comparisons were then made of the foveal avascular zone (FAZ) between groups $A$ and $B$ and of the visual fields between groups $A$ and $C$.

The right eyes of six age-matched hospital employees, two black and four white, without evidence of systemic or ophthalmological disease and with haemoglobin AA were selected as normal controls for the angiography. Informed consent was obtained from all participants.

\section{FLUORESCEIN ANGIOGRAPHY}

Fluorescein angiography of the macular region was performed with a $30^{\circ}$ Zeiss fundus camera after a rapid intravenous injection of $5 \mathrm{ml}$ of $10 \%$ sodium fluorescein through an antecubital vein followed immediately by a $5 \mathrm{ml}$ normal saline flush.

Groups A and B and the six normal controls underwent angiography. The six normal controls also underwent repeated angiography six months later to assess the reproducibility of this technique.

The negative of the angiographic frame having the highest resolution of the fovea was projected, the outline of the FAZ was drawn on a transparent overlay, and the longest diameter was measured (Figs. 1, 2A). Two of us (CML and HCC) drew and measured the FAZ of each angiogram twice in a

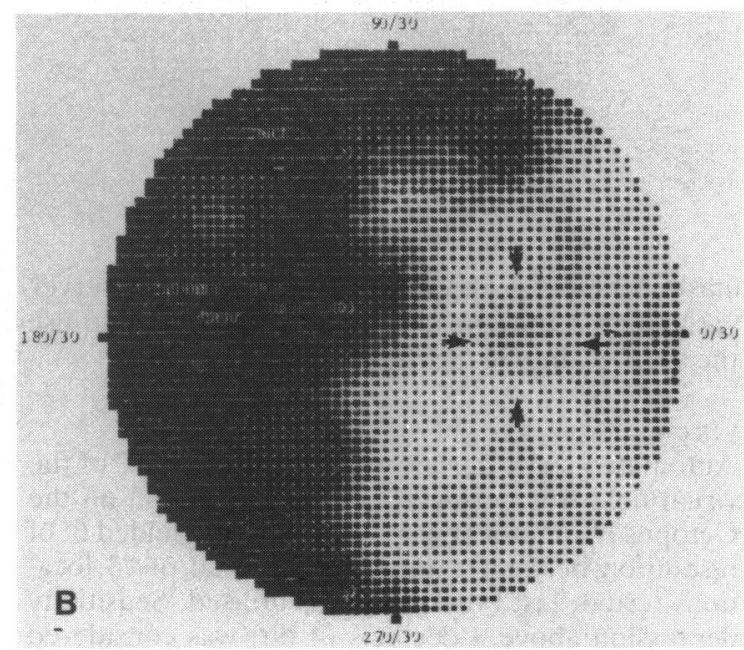

Fig. 2 (a) Fluorescein angiogram of right eye of 32-year-old SS patient (group A, case 6). The longest diameter of the FAZ is $0.58 \mathrm{~mm}$. Note paucity of capillaries close to terminal arterioles and evidence of occlusion just temporal to fovea with surrounding areas of capillary drop-out (arrows). Visual acuity is 20/20. (b) Visual field shows large scotoma. Blind spot as marked by arrows. 

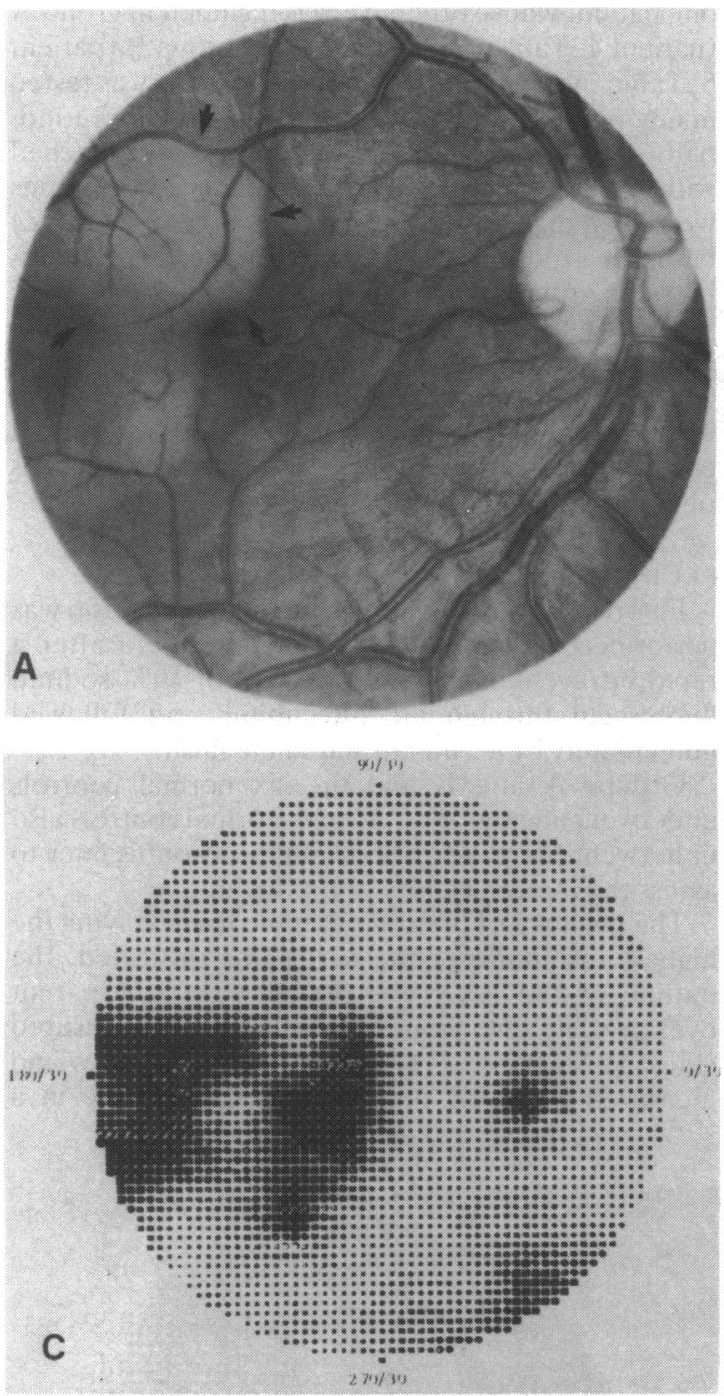

masked fashion. Less than $10 \%$ intra-or interobserver variability in these measurements allowed us to use the average among the numbers.

\section{VISUAL FIELDS}

Automated static perimetry of the central $30^{\circ}$ of the visual field was performed with Program 33 on the Octopus perimeter (Figs. 2B, 3C). This yielded $6^{\circ}$ of resolution between points, with a total of 73 locations tested; fast bracketing was utilised. Sensitivity depression above 4 decibels $(4 \mathrm{db})$ was considered abnormal for each spot. Groups A and C underwent visual field testing.

Five different values were considered. (1) A scotoma was defined as any defect of two or more

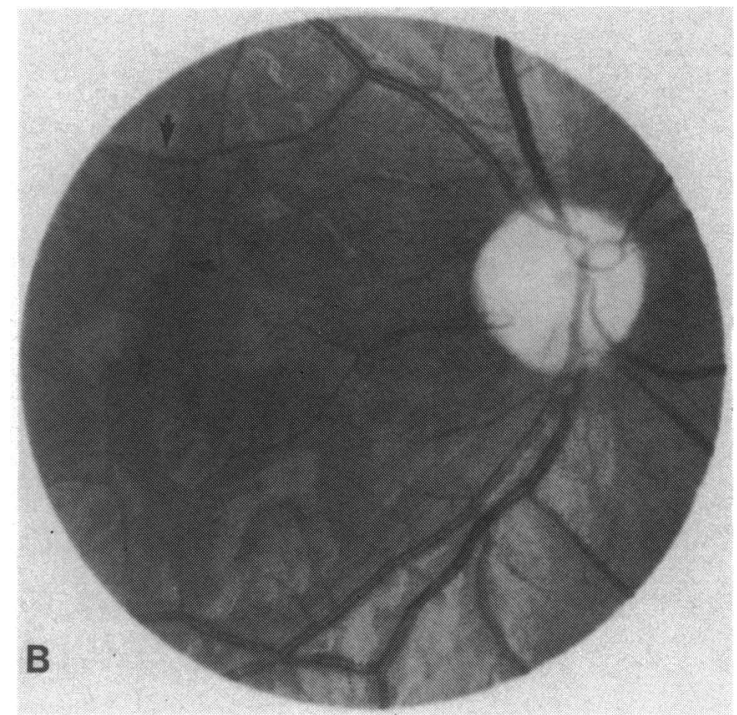

Fig. 3 (a) Fundus photograph of right eye of 18-year-old SS patient (group A, case 8) with acute retinal oedema (arrows) secondary to small artery occlusion. Visual acuity is 20/20. (b) Macular depression sign (arrows) evident 6 months later. Visual acuity is 20/15. (c) Visual field taken at time of photograph in B reveals a corresponding scotoma.

adjacent points with a threshold depression of $4 \mathrm{db}$ or greater, excluding the expected blind spot. We defined the largest scotoma as the greatest number of contiguous scotomatous points. (2) Average sensitivity depression was calculated by dividing the cumulative threshold depression in the largest scotoma by the number of points composing it. (3) The total number of defects was determined by adding all scotomatous points in the total visual field. (4) The average sensitivity depression of this value (point 3) was calculated in the same fashion as point 2. (5) The total field sensitivity depression was obtained by dividing the cumulative threshold depression of all scotomatous points by the total number of tested locations (73). 
Table 1 Group A: Eyes of sickle cell patients with maculopathy who underwent fluorescein angiography and Octopus perimetry

\begin{tabular}{lllllll}
\hline $\begin{array}{l}\text { Patient Sex } \\
\text { no. }\end{array}$ & $\begin{array}{l}\text { Age } \\
\text { (yr) }\end{array}$ & $\begin{array}{l}\text { Haemo- } \\
\text { globin } \\
\text { type }\end{array}$ & $\begin{array}{l}\text { Stage of } \\
\text { retino- } \\
\text { pathy }\end{array}$ & $\begin{array}{l}\text { Visual } \\
\text { acuity }\end{array}$ & $\begin{array}{l}\text { Fovealavascular } \\
\text { zonelongest } \\
\text { diameter }(\mathrm{mm})\end{array}$ \\
\hline 1 & M & 26 & SS & II & $20 / 30$ & $0 \cdot 71$ \\
2 & M & 36 & SC & III & $20 / 25$ & $0 \cdot 83$ \\
3 & F & 31 & SC & III & $20 / 20$ & $0 \cdot 68$ \\
4 & F & 30 & STh & II & $20 / 20$ & $0 \cdot 71$ \\
5 & M & 45 & SS & III & $20 / 20$ & $0 \cdot 89$ \\
6 & F & 32 & SS & III & $20 / 20$ & $0 \cdot 58$ \\
7 & F & 26 & STh & III & $20 / 30$ & $0 \cdot 80$ \\
8 & M & 18 & SS & I & $20 / 15$ & $0 \cdot 43$ \\
9 & F & 35 & SC & II & $20 / 20$ & $1 \cdot 0$ \\
10 & F & 46 & SC & IV & $2(0 / 20$ & $1 \cdot 42$ \\
\hline
\end{tabular}

*Goldberg. ${ }^{11}$

Table 2 Group B: Eyes of sickle cell patients without maculopathy who underwent fluorescein angiography

\begin{tabular}{|c|c|c|c|c|c|c|}
\hline $\begin{array}{l}\text { Patient } \\
\text { no. }\end{array}$ & Sex & $\begin{array}{l}\text { Age } \\
(y r)\end{array}$ & $\begin{array}{l}\text { Haemo- } \\
\text { globin } \\
\text { type }\end{array}$ & $\begin{array}{l}\text { Stage of } \\
\text { retino- } \\
\text { pathy* }\end{array}$ & $\begin{array}{l}\text { Visual } \\
\text { acuity }\end{array}$ & $\begin{array}{l}\text { Foveal avascular } \\
\text { zone longest } \\
\text { diameter }(\mathrm{mm})\end{array}$ \\
\hline 1 & $\mathbf{M}$ & 31 & SS & II & $20 / 50$ & $0 \cdot 80$ \\
\hline 2 & $F$ & 37 & SS & III & $20 / 20$ & $(0 \cdot 61$ \\
\hline 3 & $M$ & 58 & SC & III & $20 / 30$ & 0.86 \\
\hline 4 & $F$ & 14 & $\mathrm{SC}$ & III & $20 / 15$ & 0.49 \\
\hline 5 & $\mathrm{~F}$ & 30 & STh & III & $20 / 20$ & 0.55 \\
\hline 6 & $\mathbf{F}$ & 34 & STh & I & $20 / 25$ & 0.64 \\
\hline 7 & $\mathrm{~F}$ & 29 & SA & III & $20 / 30$ & $(0.43$ \\
\hline 8 & $\mathbf{M}$ & 57 & SC & III & $20 / 25$ & 0.71 \\
\hline 9 & $F$ & 35 & $\mathrm{SC}$ & II & $20 / 20$ & 0.80 \\
\hline 10 & $F$ & 31 & $\mathrm{SC}$ & III & $20 / 20$ & 0.86 \\
\hline
\end{tabular}

*Goldberg. "

Table 3 Group C: Eyes of sickle cell patients without maculopathy who underwent Octopus perimetry

\begin{tabular}{llllll}
\hline $\begin{array}{l}\text { Patient } \\
\text { no. }\end{array}$ & Sex & $\begin{array}{l}\text { Age } \\
\text { (yr) }\end{array}$ & $\begin{array}{l}\text { Haemoglobin } \\
\text { type }\end{array}$ & $\begin{array}{l}\text { Stage of } \\
\text { retinopathy* }\end{array}$ & $\begin{array}{l}\text { Visual } \\
\text { acuity }\end{array}$ \\
\hline I & M & 14 & SS & I & $20 / 20$ \\
2 & F & 30 & STh & III & $20 / 20$ \\
3 & F & 37 & SS & III & $20 / 20$ \\
4 & M & 25 & STh & I & $20 / 20$ \\
5 & M & 18 & SS & I & $20 / 15$ \\
6 & F & 45 & SC & I & $20 / 20$ \\
7 & M & 46 & SS & I & $20 / 20$ \\
8 & M & 30 & SS & I & $20 / 15$ \\
9 & F & 24 & STh & III & $20 / 15$ \\
10 & F & 33 & STh & III & $20 / 50$ \\
\hline
\end{tabular}

*Goldberg. ${ }^{1}$

\section{Results}

PATIENTS PROFILE

Group A comprised eyes with maculopathy that underwent both angiography and perimetry. The patients mean age was 32.5 years (range 18 to 46
Table 4 Foveal avascular zone: longest diameter $(\mathrm{mm})$, mean $\pm S D$

\begin{tabular}{lll}
\hline $\begin{array}{l}\text { Normal controls } \\
(n=6)\end{array}$ & $\begin{array}{l}\text { Group B, } \\
\text { without sickling } \\
\text { maculopathy } \\
(n=10)\end{array}$ & $\begin{array}{l}\text { Group A. } \\
\text { with sickling } \\
\text { maculopathy } \\
(n=10)\end{array}$ \\
\hline $0.52 \pm 0 \cdot 11$ & NS & $0 \cdot 68 \pm 0 \cdot 17$ \\
\hline
\end{tabular}

Table 5 Visual field defects in sickling maculopathy

\begin{tabular}{clll}
\hline & $\begin{array}{l}\text { Group A, } \\
\text { with } \\
\text { maculopathy } \\
(n=10) \\
\text { mean (range) }\end{array}$ & $\begin{array}{l}\text { Group C, } \\
\text { without } \\
\text { maculopathy } \\
(n=10) \\
\text { mean (range) }\end{array}$ & $\begin{array}{l}\text { Level of } \\
\text { significance }\end{array}$ \\
\hline $\begin{array}{c}\text { Worst scotoma, no. } \\
\text { of defects }\end{array}$ & $19 \cdot 2(2 \cdot 0-68 \cdot 0)$ & $0 \cdot 9(0-3 \cdot 0)$ & $\mathrm{p}<0 \cdot 01$ \\
$\begin{array}{c}\text { Average sensitivity } \\
\text { depression (db) }\end{array}$ & $12 \cdot 9(3 \cdot 2-22 \cdot 2)$ & $6 \cdot 5(0-18 \cdot 0)$ & $\mathrm{p}<0 \cdot 03$ \\
$\begin{array}{c}\text { Total no. of defects } \\
\text { Average sensitivty } \\
\text { depression (db) }\end{array}$ & $24 \cdot 7(5 \cdot 0-68 \cdot 0)$ & $2 \cdot 2(0-8 \cdot 0)$ & $\mathrm{p}<0 \cdot 01$ \\
$\begin{array}{c}\text { Total ficld sensitivity } \\
\text { depression (db) }\end{array}$ & $4 \cdot 6(0 \cdot 5 \cdot 2-20 \cdot 3)$ & $6 \cdot 4(0-18 \cdot 0)$ & $\mathrm{p}<0 \cdot 01$ \\
\hline
\end{tabular}

See 'Materials and methods' for definitions of parameters.

years). Four patients were male and six were female; all had a visual acuity equivalent to or better than 20/30 (see Table 1).

Group B contained eyes without maculopathy that underwent angiography. The patients ranged from 14 to 58 years in age (mean 35.6 years). Three patients were male and seven were female. Only one had a visual acuity of 20/50; the remaining nine had visual acuities equivalent to or better than 20/30 (see Table 2).

Group C was composed of eyes without maculopathy that underwent perimetry. The patients were from 14 to 46 years of age (mean $30 \cdot 2$ years). Five patients were male and five were female. Only one had a visual acuity of 20/50; the other nine had visual acuities equivalent to or better than 20/30 (see Table 3).

All normal controls were in their twenties; four were female and two were male. And none had evidence of ophthalmic or systemic disease at their ophthalmic examination.

FLUORESCEIN ANGIOGRAPHY

The average of the longest diameter of the FAZ measured for the six normal controls was $0.52 \mathrm{~mm}$, SD $0.11 \mathrm{~mm}$ (range 0.40 to $0.71 \mathrm{~mm}$ ). Six months later all repeated angiograms could be superimposed 
over the initial ones without change in the vascular pattern, confirming the reproducibility of this technique.

The average of the longest diameter of the FAZ measured in group A was 0.81, SD $0.27 \mathrm{~mm}$ (range 0.43 to $1.42 \mathrm{~mm}$; see Table 1 ), as compared with 0.68 , SD $0.17 \mathrm{~mm}$ (range 0.43 to $0.86 \mathrm{~mm}$ ) in group B (see Table 2). The difference between the normal controls and the patients with maculopathy (group A) was statistically significant $(p=0 \cdot 016$, Wilcoxon rank sum test; see Table 4). The difference was not statistically significant between the two subsets of sickle cell patients or between the normal controls and the patients without maculopathy, though the latter comparison approached significance $(p=0.06$, Wilcoxon rank sum test).

VISUA L FIELDS

All five values, (1) the largest scotoma, (2) average sensitivity depression of the largest scotoma, (3) total number of defects, (4) average sensitivity depression of point 3 , and (5) total field sensitivity depression, were significantly larger in group $\mathrm{A}$ than in group $\mathrm{C}$ (Table 5).

\section{Discussion}

The dimensions of the FAZ have been studied by several investigators. Trypsin digest preparations of normal human necropsy eyes have revealed longest diameters ranging from 0.40 to $0.65 \mathrm{~mm} .{ }^{12}$ Measurement of the FAZ in vivo may be obtained using fluorescein angiography; with this technique Laatikainen and Larinkari ${ }^{13}$ have estimated that the mean diameter of the capillary free zone was $70.53 \mathrm{~mm}$ in patients under age 40 and $0.61 \mathrm{~mm}$ in patients over age 40 . Recently $\mathrm{Wu}$ et al. ${ }^{14}$ have shown a similar age correlated enlargement of the FAZ; the mean longest diameter was $0.88 \mathrm{~mm}$ for 45 normal subjects ranging in age from 12 to 55 years. Bresnick et al. ${ }^{\text {is }}$ have correlated the size of the FAZ with the severity of capillary non-perfusion in the posterior pole; the median longest diameter was $0.80 \mathrm{~mm}$ in their normal controls and $0.92 \mathrm{~mm}$ in their diabetic patients. Conversely, Bird and Weale ${ }^{16}$ have found an avascular zone of only $0.20 \mathrm{~mm}$ in six subjects who visualised their retinal vasculature entoptically. The authors thought that crossing capillaries, which are often undetected by standard angiography, could be seen entoptically.

Vaso-occlusion is the precipitating event in the development of ischaemia in sickle cell retinopathy. Although the retinopathy of the sickle cell haemoglobinopathies is most frequently described in the peripheral retina, macular disease occurs in approximately $20 \%$ of cases. ${ }^{17}{ }^{11}$ The macular area is pre- disposed to vascular occlusion because end arterioles terminate along the horizontal raphe around the FAZ.

The significance of the FAZ with respect to visual function has been studied in relation to diabetes ${ }^{1+14-210}$ (Smith RT, et al., paper in preparation). All but one of our subjects who underwent angiography had excellent visual acuity, and all of the patients with maculopathy had visual acuities equivalent to or better than 20/30. None had any related visual complaints, yet their FAZ was in general uneven and displayed prominent irregularities. When compared with that of the normal controls the FAZ enlargement of the maculopathy group was statistically significant. A clear demonstration of statistical significance between those patients with and without maculopathy, however, may require a larger sample size.

Technically, the use of a saline flush after fluorescein injection provided us with much clearer and crisper views of the FAZ than could be obtained by the standard technique. The reproducibility of our technique was evidenced by the ability to superimpose over the initial angiograms the follow-up angiograms at six months in our normal controls. We are confident that measurement of the FAZ with angiography is an accurate and reliable method.

We had difficulty, however, in delineating the FAZ in four of the angiograms, in which crossing vessels through larger areas of non-perfusion were seen. We considered these crossing vessels to be part of the outline of the FAZ. We may therefore have underestimated the real dimensions of the FAZ, particularly in those patients with maculopathy.

Octopus perimetry has also been used to establish the presence of non-perfusion in the peripheral retina $^{78}$ (Charles $\mathrm{HC}$, unpublished data). In one investigation $60^{\circ}$ angiography, as compared with Octopus visual fields of the central $30^{\circ}$ and peripheral $30^{\circ}$ to $60^{\circ}$, was performed on 14 eyes with diabetes and 14 eyes with branch vein occlusion.' Good correlation was observed between regional visual field changes and retinal capillary non-perfusion; prominent areas of field depression and dropout were especially pronounced in the midperiphery in diabetic retinopathy. In another study ${ }^{*}$ areas of non-perfusion on angiography in 163 diabetic eyes correlated well with Octopus visual field defects.

We attempted to quantify the visual field defects in our patients through several manipulations of the threshold depressions via the computerised printout. We calculated the average sensitivity depression of the largest single scotoma and the total number of scotomas to determine an approximate level of threshold sensitivity. A small, very depressed or abnormal scotoma, however, would be less abnormal 
when total field sensitivity depression was calculated. The permutations performed allowed us to consider different ways of quantitating the data. Again, the sickle cell patients with maculopathy who had good visual acuity but an abnormally enlarged FAZ revealed significantly large scotomas. For each calculated value the patients with maculopathy had larger defects than those without maculopathy.

The scotomas matched well the geographic distribution of non-perfusion by angiography (Figs. 2, 3). However, the limitations of resolution in Program 33 at $6^{\circ}$ precluded the exact superimposition of the central angiograms on the visual fields. Inasmuch as their is a learning curve associated with any psychophysical measurement and the testing situation itself is a variable process, it can be argued that a single test might not be of major importance. However, the fact that every parameter studied (that is, largest scotoma) was significantly increased in the maculopathy patients shows the data to be internally consistent, thereby supporting the value of the test.

We believe that macular ischaemia is quantifiable by the two techniques presented herein: measurement of the FAZ by angiography and assessment of the depth of threshold depression by Octopus perimetry. Since all but two of our subjects had visual acuities equal to or better than 20/30, both techniques which demonstrated anatomical and functional abnormalities appear to provide a more sensitive measurement of macular disease than visual acuity testing.

We thank Maxine Gere for editorial assistance, Dorris Brown for secretarial assistance, and Norman Jednock for photography.

This work was supported in part by training grant no. HL 15168-14 and core grant no. EY 1792-07 from the National Heart Lung and Blood Institute, Bethesda, Maryland, and by unrestricted grants from Alcon Laboratories, Fort Worth, Texas, and Research to Prevent Blindness, Inc., New York City.

\section{References}

1 Blach RK. The management of the vascular retinopathies. Doc Ophthalmol Proc Ser 1975; $7: 169-80$.

2 Cunha-Vaz JG, Mota CC, Leite EC, Abreu JR, Ruas MA.
Effect of Sulindac on the permeability of the blood-retinal barricr in early diabetic retinopathy. Arch Ophthalmol 1985; 103: 1307-11.

3 Cunha-Vaz JG, Abreu JR, Campos AJ, Figo GM. Early breakdown of the blood-retinal barrier in diabetes. BrJ Ophthalmol 1975; 59: 649-56.

4 Waltman SR, Ocstrich C, Krupin T, et al. Quantitative vitreous fluorophotometry: A sensitive technique for measuring early breakdown of the blood-retinal barricr in young diabetic patients. Diabetes 1978; 27: 85-7.

5 Shimizu K, Kobayashi Y, Muraoka K. Midperipheral fundus involvement in diabetic retinopathy. Ophthalmology 1981; 88: 6061-12.

6 Niki T, Muraoka K, Shimizu K. Distribution of capillary nonperfusion in early-stage diabetic retinopathy. Ophthalmology 1984; 91: 1431-9.

7 Bell JA, Feldon SE. Retinal microangiopathy. Correlation of Octopus perimetry with fluorescein angiography. Arch Ophthalmol 1984; 102: 1294-8.

8 Federman JL, Lloyd J. Automated static perimetry to evaluate diabetic retinopathy. Trans Am Ophthalmol Soc 1984; 82: $358-70$.

9 Paylor RR, Carncy MD, Ogura Y, Cunha-Vaz JG, Jampol LM, Goldberg MF. Alteration of the blood-retinal barrier and vitreous in sickle cell retinopathy. Int Ophthalmol 1986; 9: 103-8.

$10 \mathrm{Jampol}$ LM. Arteriolar occlusive discases of the macula. Ophthalmology 1983; 90: 534-9.

11 Goldberg MF. Classification and pathogenesis of proliferative sickle retinopathy. Am J Ophthalmol 1971; 71 : 649-65.

12 Wise GN, Dollery CT, Henkind P. The retinal circulation. Hagerstown: Harper and Row, 1971: 25

13 Laatikainen L, Larinkari J. Capillary-free area of the fovea with advancing age. Invest Ophthalmol Vis Sci 1977; 16: 1154-7.

$14 \mathrm{Wu}$ L, Huang Z, Wu D, Chan E. Characteristics of the capillaryfree zone in the normal human macula. Jpn J Ophthalmol 1985; 29: $406-11$.

15 Bresnick GH, Condit R. Syrjala S, Palta M, Groo A, Korth K. Abnormalitics of the foveal avascular zone in diabetic retinopathy. Arch Ophthalmol 1984; 102: 1286-93.

16 Bird AC, Weale RA. On the retinal vasculature of the human fovea. Exp Eye Res 1974; 19: 409-17.

17 Nagpal KC, Goldberg MF, Rabb MF. Ocular manifestations of sickle hemoglobinopathies. Surv Ophthalmol 1977; 21: 391-411.

18 Stevens TS, Busse B, Lee CB, Woolf MB, Galinos SO, Goldberg MF. Sickling hemoglobinopathies: Macular and perimacular vascular abnormalities. Arch Ophthalmol 1974; 92: 455-63.

19 Klcin BEK, Davis MD, Scgal P, et al. Diabctic retinopathy: Assessment of severity and progression. Ophthalmology 1984; 91: 10-7.

20 Ticho V, Patz A. The role of capillary perfusion in the management of diabetic macular edema. Am J Ophthalmol 1973; 76: $880-6$.

Accepted for publication 27 August 1986. 